\title{
Low-pickle Processing of Leather: Assessment of Leather Tanning Quality by Methods of Thermal Analysis
}

\author{
VirgilijusVALEIKA*
} Department of Physical and Inorganic Chemistry, Kaunas University of Technology, Radvilenu pl. 19, Kaunas LT-50254,
Lithuania

crossref http://dx.doi.org/10.5755/j01.ms.26.3.22509

Received 15 January 2019; accepted 31 March 2019

\begin{abstract}
Pelt obtained by deliming with peracetic acid can be chromed after additional treatment with sodium chloride or oxalic acid solution, or directly tanned using synthetic tannins. The results of differential scanning calorimetry and thermogravimetric analyses have suggested that any tanning increases thermal stability of leather collagen. The produced chrome-free leather, despite its high tensile strength, is not characterized by high shrinkage temperature what indicates insufficient thermal stability of such leather. This fact contradicts the results of differential scanning calorimetry and thermogravimetric analyses results which show the high thermal stability of the chrome-free leather. It has been concluded that scanning calorimetry and thermogravimetric analyses are not sufficient for the appropriate assessment of leather obtained by the methods of various tanning, and the conclusions about changes in leather structure and quality of leather can not be drawn only upon results of the mentioned analyses.
\end{abstract}

Keywords: deliming, leather, tanning, crosslinking, differential scanning calorimetry, thermogravimetric analysis.

\section{INTRODUCTION}

The conventional leather processing technology is based on strong alkaline treatment of hide or skin with the purpose to remove hair and open up of derma structure. Subsequent deliming aims at removal of calcium compounds and reduce alkalinity of unhaired hide/skin. Next step, which is pickling, significantly reduces $\mathrm{pH}$ of pelt down to $2-4$, and thus the pelt characterised by such $\mathrm{pH}$ value becomes suitable for subsequent chrome tanning process.

Development of beamhouse processes such as unhairing $[1,2]$ or deliming leads to production of almost neutral [3] or even acidic pelt $[4,5]$. Accordingly, the parameters of further processing steps such as pickling and chrome or vegetable tanning can be changed seeking to diminish their impact on environment. Thanikaivelan et al. have demonstrated the possibility of chroming of pelt having $\mathrm{pH} 8$ without conventional pickling overall [6].

The attempts to develop new pickling methods for conventional alkaline pelt have been made trying to replace commonly used materials: sodium chloride and sulphuric acid by other materials such as synthesized new materials rich in sulfonic acid groups [7] or a novel pre-tanning agent Q16 synthesized from cyanuric chloride and $p$ aminobenzoic acid [8]. Unfortunately, the authors do not comment the impact on environment of the new methods.

Chromium has been used as primary tannage for many leathers for over 100 years [9]. Though chromium is considered as the best mineral-tanning agent to date it has its own negative image as well. Search for substitutes for chrome tanning has been undertaken by many researchers all over the world. The alternative tanning agent could be organic or inorganic based. Inorganic [10] or organic nonchrome tannages have gradually become preeminent in leather production [11]. An organic tanning system as a substitute for chrome tanning is considered as a suitable alternative owing to the limitations of inorganic tanning agents [12]. Since the quality of current chrome-free leather is lower due to, for example, lower resiliency and hydrothermal stability [13] new combinations of subsequent processing of pelt obtained by deliming with peracetic acid (PAA) have been explored: a) less pickle + chrome tanning; b) organic tanning directly after deliming.

The aim of this research was to investigate the possibility to use chrome-free tanning agent directly after deliming with PAA and bating, and to assess the accordance of the leather properties and results of differential scanning calorimetry (DSC), thermosgravimetric (TG) and physicalmechanical analyses.

\section{EXPERIMENTAL}

\subsection{Parameters of processes}

Cattle hide (mass $22.8 \mathrm{~kg}$ ) preserved by $\mathrm{NaCl}$ was used for experiments. The hide was processed up to tanned leather with the aim to produce tanned leather ("wet white" or "wet blue") as follows:

Soaking ( $\%$ based on hide mass): $\mathrm{H}_{2} \mathrm{O} 100 \%$, at $18-22{ }^{\circ} \mathrm{C}, \mathrm{Na}_{2} \mathrm{CO}_{3} 1.4 \%$, duration $8.5 \mathrm{~h}$, run continuously.

Washing: $\mathrm{H}_{2} \mathrm{O} 200 \%$, temperature $20-22{ }^{\circ} \mathrm{C}$, duration $15 \mathrm{~min}$, run continuously.

Liming (total duration $24 \mathrm{~h}$ ): a) $\mathrm{H}_{2} \mathrm{O} 100 \%$, at $20-22{ }^{\circ} \mathrm{C}$, detergent $0.1 \%$, duration $30 \mathrm{~min}$, run continuously; b) $\mathrm{Na}_{2} \mathrm{~S} 1.2 \%, \mathrm{Ca}(\mathrm{OH})_{2} 2.3 \%$, duration $1.5 \mathrm{~h}$, run continuously; c) $\mathrm{Ca}(\mathrm{OH})_{2} 2.3 \%$, duration $1 \mathrm{~h}$, run

\footnotetext{
* Corresponding author. Tel.: +370-37-300189; fax: +370-37-300152.

E-mail address: virgilijus.valeika@ktu.lt (V. Valeika)
} 
continuously; d) $\mathrm{H}_{2} \mathrm{O} 100 \%$, at $20-22{ }^{\circ} \mathrm{C}$, duration $30 \mathrm{~min}$; run continuously. Leave stand until morning.

Washing (two times): a) $\mathrm{H}_{2} \mathrm{O} 200 \%$, temperature $20-22{ }^{\circ} \mathrm{C}$, duration $30-\min$, run - continuously, drain.

Deliming ( $\%$ based on pelt mass):

$1^{\text {st }}$ variant: conventional deliming-bating (control): a) $\mathrm{H}_{2} \mathrm{O} 40 \%$, at $33-38{ }^{\circ} \mathrm{C}, \mathrm{NH}_{4}\left(\mathrm{SO}_{4}\right)_{2} 2.2 \%$, duration 30 min, run continuously; b) $\mathrm{NH}_{4}\left(\mathrm{SO}_{4}\right)_{2} 1.5 \%$, duration 30 min, run continuously; c) $\mathrm{H}_{2} \mathrm{O} 100 \%$, EP Oropon ON2 (Röhm GmbH \& Co, Germany) $0.15 \%$, duration $1 \mathrm{~h}$, run continuously.

$2^{\text {nd }}$ variant: deliming with peracetic acid (PAA) and bating (experimental): a) $\mathrm{H}_{2} \mathrm{O} 40 \%$, temperature $36-38^{\circ} \mathrm{C}$, PAA $0.75 \%$, pH of PAA solution 4.0, duration $1 \mathrm{~h}$, run continuously; b) EP Novo Bate WB (Novozymes, Denmark) $0.30 \%$, duration $1 \mathrm{~h}$, run continuously ( $\mathrm{pH}$ of solution at end of the process 4.86).

Washing (two times): $\mathrm{H}_{2} \mathrm{O} 100 \%$, temperature $20-22{ }^{\circ} \mathrm{C}$, duration $20 \mathrm{~min}$, run continuously, drain.

Treatment before tanning ( $\%$ based on pelt mass):

$1^{\text {st }}$ variant: pickling (control): a) $\mathrm{H}_{2} \mathrm{O} 40 \%$, temperature $20-22{ }^{\circ} \mathrm{C}, \quad \mathrm{NaCl}-5.5 \%$, duration $15 \mathrm{~min}$, run continuously; b) $\mathrm{HCOONa} 1 \%$, duration $20 \mathrm{~min}$, run continuously; c) $\mathrm{H}_{2} \mathrm{SO}_{4} 0.5 \%$, duration $15 \mathrm{~min}$, run continuously; d) $\mathrm{H}_{2} \mathrm{SO}_{4} 0.5 \%$, duration $15 \mathrm{~min}$, run continuously; e) $\mathrm{H}_{2} \mathrm{SO}_{4} 0.5 \%$, duration $15 \mathrm{~min}$, run continuously; f) $\mathrm{H}_{2} \mathrm{SO}_{4} 0.5 \%$, duration $5 \mathrm{~h}$, run continuously (final $\mathrm{pH}$ of solution 3.18).

$2^{\text {nd }}$ variant: treatment with $\mathrm{NaCl}: \mathrm{H}_{2} \mathrm{O} 40 \%$, at $20-22{ }^{\circ} \mathrm{C}, \mathrm{NaCl} 6 \%$, duration $2 \mathrm{~h}$, run continuously (final $\mathrm{pH} 4.84)$.

$3^{\text {rd }}$ variant: treatment with oxalic acid: $\mathrm{H}_{2} \mathrm{O} 40 \%$, HOOCCOOH $0.1 \%$, temperature $20-22{ }^{\circ} \mathrm{C}$, duration $1 \mathrm{~h}$, run continuously (final $\mathrm{pH} 4.65$ ).

Crome tanning (in pickling or other treatment before tanning solution (\% based on pelt mass): a) Cromeco EXTRA (Gruppo Chimico Dalton, Italy) $1.5 \%$ (counting to $\mathrm{Cr}_{2} \mathrm{O}_{3}$ ), temperature $20-22^{\circ} \mathrm{C}$, duration $12 \mathrm{~h}$, run continuously; b) Neutragene MG-120 (Codyeco s.p.a., Italy) $0.25 \%$, duration $2 \mathrm{~h}$, run continuously; c) Neutragene MG-120 $0.25 \%$, duration $2 \mathrm{~h}$, run continuously; d) $\mathrm{H}_{2} \mathrm{O} 40 \%$, temperature $55^{\circ} \mathrm{C}$, duration $1 \mathrm{~h}$, run continuously.

Organic tanning: $\mathrm{H}_{2} \mathrm{O} 110 \%$ (\% based on pelt mass), temperature $25-26^{\circ} \mathrm{C}$, synthan Blancotan $W$ (Silva, Argentine) $20 \%$, duration $48 \mathrm{~h}$, run continuously.

Hide or leather samples used for investigation: $1^{\text {st }}$ - limed pelt;

$2^{\text {nd }}-$ conventionally delimed, pickled and chromed leather (control leather);

$3^{\text {rd }}-$ delimed with PAA, treated with $\mathrm{NaCl}$ solution before chroming and chromed leather; $4^{\text {th }}-$ delimed with PAA, treated with oxalic acid solution before chroming and chromed leather;

$5^{\text {th }}-$ delimed with PAA and directly tanned with synthetic tannin Blancotan W leather.

\subsection{Methods of analyses}

The shrinkage temperature of pelt was measured according to standard [14]. The shrinkage temperature of chromed leather samples was determined as described in the literature using special equipment and replacing the distilled water with glycerol [15].

The tensile strength and relative elongation of pelt and chrome-tanned leather were measured with dynamometer according standard [16].

DSC and TG analyses were performed with the Netzsch Gerätebau $\mathrm{GmbH}$ (Germany) thermal analyzer in nitrogen atmosphere at the heating rate of $10^{\circ} \mathrm{C} / \mathrm{min}$. The reference was an empty aluminium pan. Before the DSC and TG analyses the samples of pelt and leather were dehydrated using acetone [17].

\section{RESULTS AND DISCUSSION}

Chrome-free leather such as the one tanned with synthetic or natural tannins behaves very differently from chrome tanned leather [18]. Accordingly, in order to assess the difference between these leather types, physical, mechanical indexes, and shrinkage temperature $\left(T_{\mathrm{S}}\right)$ of samples were determined (Table 1) first.

The chrome-free samples are characterised by the highest tensile and grain strength (Table 1). This phenomenon is described in literature [18]. Synthetic tannins fill better leather matrix, therefore, tanned leather has better strength properties. Unfortunately, structure of the chrome-free leather structure is not as elastic as that of the chromed leather: the elongation of chrome-free leather is markedly lower comparing with the chromed one. Additionally, a value of shrinkage temperature shows low thermal stability of the chrome-free leather. The chromefree tanning has increased shrinkage temperature only by $6{ }^{\circ} \mathrm{C}$ comparing with $T_{\mathrm{S}}$ of the limed pelt.

The results of DSC and TG analyses allowed obtaining more detailed information about thermal behaviour of differently tanned leather. The thermograms are presented in Fig. 1. The peak of the first temperature effect is at $82{ }^{\circ} \mathrm{C}$ for the limed pelt and in the range of $86-90{ }^{\circ} \mathrm{C}$ for variously tanned leather. Therefore, tanning has increased the temperature of this effect in all cases.

Mostly, this effect is attributed to elimination of capillary moisture [19]. The moisture evaporates as at higher temperature as capillaries are narrower. Of course, due to swelling effect the capillaries in derma are larger after liming than after tanning.

Table 1. Qualitative indexes of limed pelt and chromed leather

\begin{tabular}{|c|c|c|c|c|c|}
\hline \multirow{2}{*}{ Indexes } & \multicolumn{5}{|c|}{ Sample } \\
\hline & $1^{\text {st }}$ & $2^{\text {nd }}$ & $3^{\text {rd }}$ & $4^{\text {th }}$ & $5^{\text {th }}$ \\
\hline Tensile strength, $\mathrm{N} / \mathrm{mm}^{2}$ & $13.5 \pm 0.84$ & $19.2 \pm 1.08$ & $20.1 \pm 1.51$ & $20.0 \pm 1.78$ & $21.3 \pm 1.17$ \\
\hline Grain strength, N/mm ${ }^{2}$ & - & $16.4 \pm 1.12$ & $15.5 \pm 1.08$ & $12.0 \pm 0.94$ & $20.0 \pm 1.02$ \\
\hline Relative elongation when load is $10 \mathrm{~N} / \mathrm{mm}^{2}, \%$ & $54.5 \pm 4.01$ & $45.2 \pm 2.30$ & $52.5 \pm 3.30$ & $48.5 \pm 2.30$ & $31.5 \pm 2.15$ \\
\hline Shrinkage temperature $\left(T_{\mathrm{S}}\right),{ }^{\circ} \mathrm{C}$ & $56.0 \pm 0.62$ & $101.0 \pm 1.12$ & $101.7 \pm 1.14$ & $104.0 \pm 1.18$ & $62.0 \pm 0.70$ \\
\hline
\end{tabular}


Other explanation of the first effect is based on the number of hydrogen bonds [19-22]: the higher temperature and larger area of peak can be observed when more hydrogen or cross-linking bonds are formed in the collagen. According to this point of view, it can be proposed that treatment with Blancotan $\mathrm{W}$ is a good way to increase the stability of leather, but the value of shrinkage temperature of the sample tanned with Blancotan $\mathrm{W}$ does not confirm this assumption. Temperature interval of $200-220{ }^{\circ} \mathrm{C}$ is attributed to melting point of crystalline part of collagen, i.e. transition of collagen from high elasticity state to viscousflow state [23]. This peak is characteristic to limed pelt or chrome-free leather only (Fig. $1,1^{\text {st }}$ and $5^{\text {th }}$ sample), i.e. the peak disappears during chrome tanning. This dependence can be explained by deep penetration of chromium compounds into collagen matrix [23]. Presence of this peak indicates the other behaviour and structural properties of chrome-free leather in comparison with chrome-tanned one. It could be proposed that chrome-free leather has properties of tanned leather and pelt simultaneously.

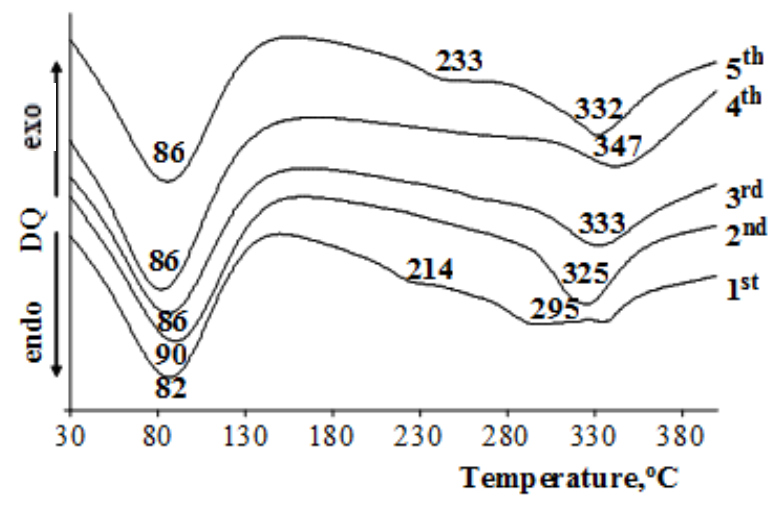

Fig. 1. DSC curves of samples

The third peak is attributed to leather collagen destruction [19-22]. The results show (Fig. 1) that tanning increases the destruction temperature $\left(T_{\mathrm{D}}\right)$ independently of the tanning method. The limed pelt sample has the lowest $T_{\mathrm{D}}\left(295^{\circ} \mathrm{C}\right)$ and sample delimed with PAA, treated with oxalic acid solution and chromed has higher $T_{\mathrm{D}}\left(347^{\circ} \mathrm{C}\right)$. The $T_{D}$ values correlate with shrinkage temperature (Fig. 2), but DSC analysis shows too high thermal stability of chrome-free leather. High $\mathrm{T}_{\mathrm{D}}$ value can be attributed to big amount of used synthetic tannins in the tanned leather and, accordingly, this high value does not approve high thermal stability of the leather but rather is related with high thermal stability of the used synthetic tanning agent.
The TG analysis is used in many fields of material research. Due to complexity of leather materials, there are a variety of thermal degradation behaviours of modified collagen fibres in different leathers [24]. TG analysis could give some useful guidance for improvement the leathermaking technology and confirm DSC analysis results in the same time.

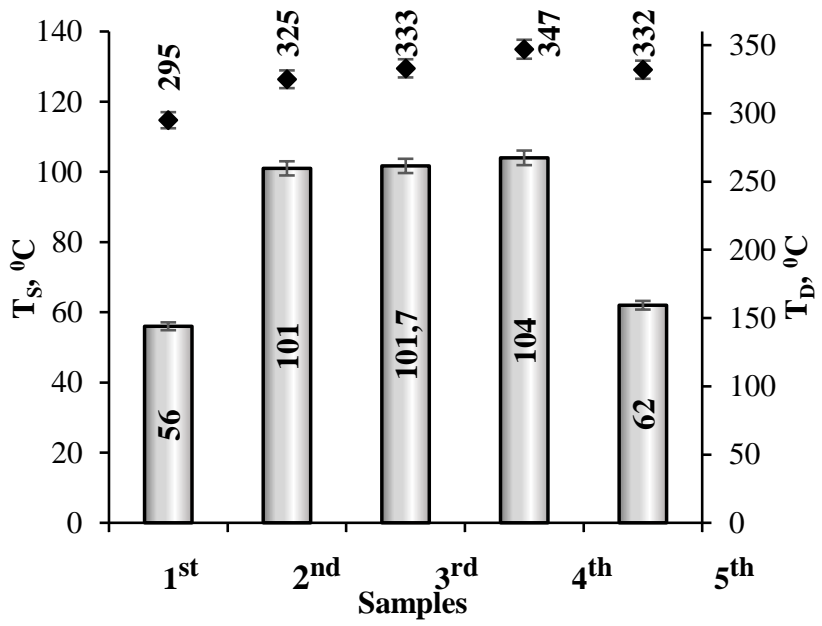

Fig. 2. The $T_{\mathrm{S}}$ and $T_{\mathrm{D}}$ temperature dependence on leather tanning method

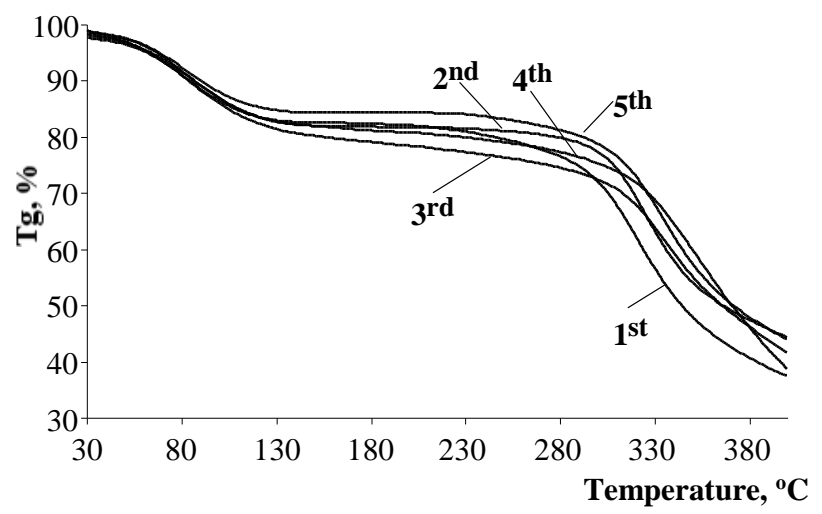

Fig. 3. TG curves of samples

On the other hand, the thermal stability comparative studies between wet-white (chrome-free) and wet-blue (chromed leather) carried out by Rosu et al. [25] exhibited a similar general thermal behaviour of the both leathers. It was observed that, for the wet-blue leather, the presence of $\mathrm{Cr}$ slightly increased the thermal stability, due to the formation of more stable characteristic metal-collagen complexes [25].

Table 2. The influence of sample weight loss on treatment method

\begin{tabular}{|c|c|c|c|c|c|}
\hline \multirow{2}{*}{ Temperature, ${ }^{\circ} \mathrm{C}$} & \multicolumn{5}{|c|}{ Sample weight loss, \% } \\
\cline { 2 - 6 } & $1^{\text {st }}$ & $2^{\text {nd }}$ & $3^{\text {rd }}$ & $4^{\text {th }}$ & $5^{\text {th }}$ \\
\hline 50 & 3.4 & 3.1 & 3.0 & 2.5 & 2.4 \\
\hline 100 & 13.5 & 13.1 & 14.0 & 13.1 & 12.0 \\
\hline 150 & 17.4 & 17.9 & 19.7 & 17.9 & 15.5 \\
\hline 200 & 17.9 & 18.2 & 21.5 & 19.2 & 15.6 \\
\hline 250 & 20.3 & 18.9 & 23.6 & 20.9 & 16.8 \\
\hline 300 & 28.0 & 22.7 & 27.6 & 24.7 & 21.2 \\
\hline 350 & 52.2 & 46.0 & 45.0 & 40.3 & 42.8 \\
\hline 400 & 62.5 & 55.5 & 58.3 & 61.1 & 55.9 \\
\hline
\end{tabular}


The thermo-gravimetric curves of limed pelt, chrome tanned, and chrome-free leather are presented in Fig. 3. The weight loss dependence on treatment method is presented in Table 2. It is seen (Fig. 3 and Table 2) that limed pelt sample loses weight faster ( $1^{\text {st }}$ sample). This can be explained by lower thermal stability of limed pelt collagen comparing with chromed leather. The tanning increases stability independently on the method of tanning (Table 2).

\section{CONCLUSIONS}

Pelt obtained by deliming with peracetic acid can be chromed after additional treatment with sodium chloride or oxalic acid solution, or directly tanned using synthetic tannins. Based only on the results of differential scanning calorimetry and thermogravimetric analyses is has been proposed that any tanning increases thermal stability of collagen of leather. Unfortunately, the produced chromefree leather despite its high tensile strength is not characterized by high shrinkage temperature what indicates insufficient thermal stability of such leather. This fact contradicts results of differential scanning calorimetry and thermogravimetric analyses showing the high thermal stability of the chrome-free leather.

Accordingly, the results obtained by scanning calorimetry and thermogravimetric analyses are not sufficient for the appropriate assessment of leather obtained by the methods of various tanning, and the conclusions about changes in leather structure and quality of leather cannot be drawn only upon results of the mentioned analyses.

\section{REFERENCES}

1. Aravindhan, R., Saravanabhavan, S., Rao, J.R., Nair, B.U. A Bio-driven Lime and Pickle Free Tanning Paves Way for Greener Garment Leather Production Journal of the American Leather Chemists Association 99 (2) 2004: pp. 53-66.

2. Valeika, V., Beleska, K., Sirvaityte, J. Alkaline-free Method of Hide Preparation to Tanning Brazilian Journal of Chemical Engineering 29 (2) 2012: pp. 315-323. http://dx.doi.org/10.1590/S0104-66322012000200012

3. Zeng, Y.H., Lu, J.H., Liao, X.P., He, Q., Shi, B. Non-ammonia Deliming Using Sodium Hexametaphosphate and Boric Acid Journal of the American Leather Chemists Association 106 (9) 2011: pp. 257-263.

4. Širvaitytė, J., Valeika, V., Beleška, K., Valeikienė, V. Action of Peracetic Acid on Calcium in Limed Pelt Journal of the Society of Leather Technologists and Chemists 91 (3) 2007: pp. 123-127.

5. Širvaitytė, J., Valeika, V., Plavan, V. Peracetic Acid Deliming. Part II: Pickle-free and Low-pickle Processing of Peracetic Acid Delimed Pelt Journal of the Society of Leather Technologists and Chemists 93 (2) 2009: pp. 40-45.

6. Thanikaivelan, P., Rao, J.R., Nair, B.U. Development of Leather Processing Method in Narrow pH Profile: Part 2. Standardisation of tanning process Journal of the Society of Leather Technologists and Chemists 85 (3) 2001: pp. 106- 115 .

7. Zhang, H., Chen, X.X., Wang, X.C., Qiang, X.H., Li, X.N., Li, M. A Salt-free Pickling Chrome Tanning Approach Using a Novel Sulphonic Aromatic Acid Structure Journal of Cleaner Production 142 (4) 2017: pp. $1741-1748$. https://doi.org/10.1016/j.jclepro.2016.11.113

8. Cui, L., Qiang, X.H., Yu, L., Wei, X., Li, C.T. A Cleaner Method for Low-Chrome Tanning with No-Salt Pickling
Journal of the Society of Leather Technologists and Chemists 101 (5) 2017: pp. 219-226.

9. Musa, A.E., Gasmelseed, G.A. Semi-Chrome Upper Leather from Rural Goat Vegetable Tanned Crust Journal of Applied and Industrial Sciences 1 (1) 2013: pp. 43-48.

10. Plavan, V., Valeika, V., Kovtunenko, O., Širvaityte, J. THPS Pretreatment before Tanning (Chrome or Non-chrome) Journal of the Society of Leather Technologists and Chemists 93 (5) 2009: pp. 186-192.

11. Prentiss, W.C., Siegler, M., Brown, E.M. Chrome Free Tanning Compositions and Processes Journal of the American Leather Chemists Association 98 (2) 2003 pp. 63-69.

12. Saravanabhavan, S., Raghava Rao, J., Unni Nair, B., Thanikaivelan, P., Chandrasekaran, B.A. A New Leathermaking Process for Meeting Eco-label Standarts: Processing of Goatskins Journal of the American Leather Chemists Association 101 (5) 2006: pp. 192-205.

13. Valeika, V., Sirvaityte, J., Beleska, K. Estimation of Chromefree Tanning Method Suitability in Conformity with Physical and Chemical Properties of Leather Materials Science (Medziagotyra) 16 (4) 2010: pp. 330-336.

14. Standard ISO 3380: 2002. Leather - Physical and mechanical tests - Determination of shrinkage temperature up to 100 degrees C.

15. Golovteeva, A.A., Kutsidi, D.A., Sankin, L.B. Laboratornyj Praktikum po Khimiyi i Tekhnologiyi Kozhy i Mekha. Legkaiya i Pischevaiya Prom. Moscow, 1982. (in Russian).

16. Standard ISO 3376:2002. Leather - Physical and Mechanical Tests - Determination of Tensile Strength and Percentage Extension.

17. Pat. USSR 767649. Method of Determination of Leather Quality.

18. Liu, C.K., Latona, N.P., DiMaio, G.L., Cooke, P.H. Viscoelasticity Studies for a Fibrous Collagen Material: ChromeFree Leather Journal of Materials Science 42 (20) 2007: pp. $8509-8516$. https://doi.org/10.1007/s 10853-007-1744-1

19. Mano, V., Scarpelli Ribeiro e Silva, M.E. Bioartificial Polymeric Materials Based on Collagen and Poly(Nisopropylacrylamide) $\quad$ Materials Research $10(2)$ 2007: pp. $165-170$. http://dx.doi.org/10.1590/S1516-14392007000200012

20. Yao, Q., Chen, H.L., Huang, H.H., Liu, B.L. Mechanism and Effect of Hydroxyl-terminated Dendrimer as Excellent Chrome Exhausted Agent for Tanning of Pickled Pelt Journal of Cleaner Production 202 2018: pp. 543-552. https://doi.org/10.1016/j.jclepro.2018.08.164

21. Onem, E., Yorgancioglu, A., Karavana, H.A., Yilmaz, O. Comparison of Different Tanning Agents on the Stabilization of Collagen via Differential Scanning Calorimetry Journal of Thermal Analysis and Calorimetry 129 (1) 2017: pp.615-622. https://doi.org/10.1007/s10973-017-6175-x

22. Hui, C., Zhi-Hua, S. Changes in Hydrothermal Stability of Collagen with Several Catechin-Metal Compounds: A DSC Study Journal of The Society of Leather Technologists and Chemists 92 (3) 2008: pp. 93-95.

23. Ostachenko, L.S., Kutiatin, G.I. Termographicheskoe i Thermogravimetricheskoe Isledovanyie Chromovych Kozh Razlichnoy Intensivnosti Dublenyia Kozhevenno-obuvnaiya promyshlennost 8 1973: pp.51-55. (in Russian).

24. Tang, K., Wang, F., Liu, J., Liu, J., Wang, Q.J. Preliminary Studies on the Thermal Degradation Kinetics of Cattlehide Collagen Fibers Journal of the American Leather Chemists Association 99 (10) 2004: pp. 401-408.

25. Rosu, L., Varganici, C.D., Crudu, A.M., Rosu, D. Influence of Different Tanning Agents on Bovine Leather Thermal Degradation Journal of Thermal Analysis and Calorimetry 134 (1) 2018 pp. $583-594$. https://doi.org/10.1007/s10973-018-7076-3 